\title{
Accounting and Value Relevance of Intangibles: A longitudinal Study in Italian Stock Exchange 2010-2018
}

\author{
Francesco Paolone, Riccardo Tiscini, Laura Martiniello \\ Mercatorum University, Rome, Italy
}

\begin{abstract}
This paper aims at exploring whether single items of intangible recognized in the financial statements under International Financial Reporting Standards (IFRS) are value relevant to investors on the Italian Stock Exchange. The data were gathered from all non-financial Italian listed companies covering the period 2010-2018. Using the Ohlson's (1995) model, a panel data regression analysis with fixed effect has been adopted to test the relationship between intangibles and stock prices. We found that intangibles (goodwill, R \& D expenditure, and other intangibles that are the sub-categories displayed on Orbis Database) are positively related to security price. The implications involve managers that must give much interest to intangibles as well as standards setters that should require further disclosure. This work covered a very recent set of longitudinal accounting data and offered an updating view of the association between intangible information and value relevance in the Italian Stock Exchange.
\end{abstract}

Keywords: International accounting, intangibles, Ohlson's model, IAS 38, IFRS 3

\section{Introduction}

The main purpose of accounting and financial reporting is facilitating investors to make economic decisions and assessing the value of firms (Barth, Beaver, Hand, \& Landsman, 2005) following the so-called shareholder value approach. The relevance of accounting information has been continually debated in the literature with the "value relevance" concept, which indicates the way by which accounting items can explain market valuation (Beisland, 2009). According to Dumontier and Labelle (1998), the value relevance shows how accounting can provide useful items facilitating investors' decisions. Many prior works on accounting have demonstrated that accounting information play a leading role in determining equity valuation (Collins, Maydew, \& Weiss, 1997; Marquardt \& Wiedman, 2004), mainly assuming that equity book value and earnings are free of reporting biases.

Overall, financial statements have the ability to capture accounting information (Francis \& Schipper, 1999). According to the accrual-based principle that has been always used to record accounting transactions, Income Statement (IS) and Balance Sheet (BS) represent the main sources of information (Bhandari \& Iyer, 2013).

The widespread of the new technologies has pushed many scholars to study the role of intangible assets that have represented a critical component of business value (Lev, 2001). There has been raised a critical and ongoing debate that arise in accounting for intangibles (Francis \& Schipper, 1999; Lev, 2001; Lev \& Zarowin,

Francesco Paolone, Ph.D., associate professor of accounting, Faculty of Economics, Mercatorum University, Rome, Italy. Riccardo Tiscini, Ph.D., full professor of accounting, Faculty of Economics, Mercatorum University, Rome, Italy. Laura Martiniello, Ph.D., associate professor of finance, Faculty of Economics, Mercatorum University, Rome, Italy. 
1999). The debate on the association between intangibles and value relevance has produced mixed results (Brown, Lo, \& Lys, 1999; Collins et al., 1997; Francis \& Schipper, 1999; Harris, Lang, \& Möller, 1994; Joos \& Lang, 1994; Lev \& Zarowin, 1999; Wang, 2018).

According to the European Union Regulation 1606/2002, the intangible assets have also witnessed an international mandatory process of accounting recognition from 2005 onwards: The international literature argues that the system of Continental European countries has shifted from a bank-oriented system, traditionally adopted by Continental European countries, towards a market based ones.

The issue we seek to address is:

Are recognized intangible assets value-relevant to investors in Italy? More specifically: Do intangible assets help in explaining the variation of market values? Are there some specific subclasses of intangible assets that play a relevant role in the relation with stock price?

This paper provides empirical results about the value relevance of accounting items by focusing on recognized intangibles assets after the Italian's adoption of International Accounting Standard (IAS) 38 and IFRS 3.

The data were gathered from all non-financial Italian listed companies from 2010 to 2018. Starting with the Ohlson's (1995) model, a panel data regression analysis with fixed effect was used. Earnings, goodwill and research and development expenses are found to be strongly associated with security price. The results we provide must be used by practitioners, investors' standard setters and auditors since it offers useful elements on accounting for intangibles and the implications of the IFRS adoption for valuation purposes.

In line with prior studies on intangibles (Oliveira, Rodrigues, \& Craig, 2010), our study contributes to the existing literature by providing empirical evidence that the intangible assets of the largest Italian companies contain a set of crucially relevant information content for investors in capital markets. Italian standard setters must give more interest to intangibles, in order to improve the content of financial statements and increase the relevance of accounting items.

The paper is structured as follows. In Section 2, we discuss relevant prior literature on intangibles and value relevance, the process of implementation of IAS 38 and IFRS3 and the hypothesis provided. In Section 3, we describe the general research design of the study and, in particular, the sample, the variables and the model adopted in the empirical work, together with the result. In the last section, we conclude with a summary of the main points made and some suggestions for future research avenues.

\section{Theoretical and Institutional Background and Hypotheses Development}

\section{The Adoption of IAS 38 and IFRS 3 in Italian Context}

The IFRS adoption produced important changes in Italy. The IAS 38 sets the rules for accounting recognition of the intangible assets (Reilly, 1999; Smith, 2000; Daum, 2003).

On the basis of Framework (par. 49) an asset is a "resource controlled by the entity, as a result of past events, from which future economic benefits are expected to flow to the entity". The economic benefit of an asset is due to its direct or indirect contribution to producing cash flow.

According to the Framework, an intangible asset to be recognized in the balance sheet must satisfy three conditions: identifiability, control, and future economic benefits. If at least one of the three conditions is missing the cost must be recorded in the profit and loss account; on the other hand, if all conditions are satisfied 
the cost of intangible asset goes to the balance sheet.

The convergence to IFRS 3 has led to some contributions (Ball, 2006; Barth, Hodder, \& Stubben, 2008; Horton, G. Serafeim, \& I. Serafeim, 2013; Sahut, Boulerne, \& Teulon, 2011; Schipper, 2005). In particular, several scholars have discussed on goodwill and value relevance focusing on the intangibles recognition pre-IFRS and post-IFRS adoption (Oliveira et al., 2010; Sahut et al., 2011).

Most of these studies demonstrated that goodwill can better explain market values in post-IFRS adoption (Chalmers, Clinch, Godfrey, \& Wei, 2012; Goodwin, Ahmed, \& Heaney, 2008; Oliveira et al., 2010). Under IFRS 3 requirements, all identifiable assets and liabilities of the acquired firm must be recorded at acquisition price by determining the goodwill value (IASB, 2008a). This means that the value of intangibles in the acquired firm's book, which were not allowed to be recognized as intangibles according to the stringent IAS 38 requirements, could now be recognized (IASB, 2004a).

\section{Literature Review on Intangibles (Goodwill, R \& D and Other) and Value Relevance}

The aim of value relevance is to discover potential relationship between financial statement information and effective firm's value (Dahmash \& Qabajeh, 2012). This requires testing the statistical associations between accounting items and market values and measuring the relevance of those items to explain market values. Financial statements have recently lost their relevance in showing stock price (Brown et al., 1999; Graham, King, \& Bailes, 2000; Dontoh, Radhakrishnan, \& Ronen, 2007). Other studies found a decreasing value of earnings and increasing value of equity to predict market values (Collins et al., 1997; Ely \& Waymire, 1999; Hail, 2013; Lam, Sami, \& Zhou, 2013). This means that sometimes earnings and book values do not affect stock prices in the same way.

The value relevance of intangibles has been debated since the beginning of 90s. According to Landsman and Maydew (2002), since the business economy worldwide has changed from one based on tangible and material resources to one based on intangibles, and accounting information is not able to capture this shifting anymore.

Aboody and Lev (1998) concluded that investments in software contain relevant information for investors. Using Australian data, Barth and Clinch (1998) showed a positive relationship between intangible assets and both market and non-market-based value estimates. Some scholars (Abrahams \& Sidhu, 1998; Godfrey \& Koh, 2001; Kimouche \& Rouabhi, 2016; Shahwan, 2008; Harto \& Paranti, 2017) documented a positive relationship between intangible assets and market-based value estimates; specifically, Goodwin and Ahmed (2006) found that capitalized intangible assets may increase value relevance. After reviewing prior studies, they found that IFRS adoption improves the information scope of accounting measures, in particular, the content of goodwill and intangible assets.

In relation to the R \& D costs and value relevance, there have been several studies. Zhao (2002) found that the information provided by $\mathrm{R} \& \mathrm{D}$ items increases the level of security price. Cazavan-Jeny and Jeanjean (2003) discovered a positive relation between the capitalized R \& D cost and market price and a negative association between R \& D cost (annually recorded) with market values. Sougiannis (1994) found that investors recognize a high value on intangible assets, specifically for each one-dollar of $\mathrm{R} \& \mathrm{D}$ expenditures there would be a five-dollar in stock price.

As noted, the international debate on the effect of accounting information, specifically intangibles, and stock price has led to mixed results (Brown et al., 1999; Francis \& Schipper, 1999; Harris et al., 1994; Joos \& Lang, 1994; Lev \& Zarowin, 1999). 
The mixed results can be explained with the awareness that European countries have faced changes from bank-based systems towards market-oriented ones, with significant consequences on national accounting systems. The effect of those changes was the IFRS adoption by European listed companies from 2005 onwards, as required by European Union Regulation 1606/2002 that was enacted with the aim "to ensure a high degree of transparency and comparability for financial reporting in the Community".

According to prior contributions, we measure the value relevance of intangibles in Italian Stock Exchange and we address the research question seeking to explore whether intangible assets help investors to explain the changes of stock prices. In line with Al-Jifri and Citron (2009) and Oliveira et al. (2010), we expect that intangibles are relevant in explaining market prices. Therefore, our hypothesis is following reported:

$\mathrm{H}_{1}$ : Recognized intangible assets are value-relevant in explaining market equity value in Italy.

\section{Methodology and Results}

This section describes the dataset and measurement of variables, and the empirical model.

\section{Dataset and Model Specification}

The sample firms are selected from the Orbis Database using the following criteria:

- availability of data to calculate book value of equity, earnings, intangible assets (goodwill, R \& D expenses, other intangible assets) for the period 2010-2018;

- availability of annual market capitalization and number of outstanding shares to calculate security returns for the same period;

This selection procedure resulted in a sample of 224 listed companies (2,016 observations in total) along nine years (2010-2018). The analysis focuses upon security returns and their relationship to the level of equity, earnings and recognized intangible assets and reported goodwill.

According to prior studies, if accounting information represents a set of good summary measures of the events incorporated in stock prices, they are value-relevant because they provide a value of the firm which is close to its market value (Dumontier \& Raffournier, 2002; Oliveira et al., 2010)

$$
\text { Model 1: } \text { MVPS }_{\mathrm{it}}=\beta_{0}+\beta_{1} \mathrm{BVPS}_{\mathrm{it}}+\beta_{2} \mathrm{EPS}_{\mathrm{it}}+\varepsilon
$$

where market value per share (MVPS): Security price for the year defined as market capitalization divided by the number of outstanding shares. The security price is calculated on the first trading day following the date of the auditor's report (Talkhan, 2017); book value per share (BVPS): Annual book value of equity divided by the number of outstanding shares; earnings per share (EPS): Net income after taxes and before extraordinary items, discontinued operations, special and non-operating items.

According to other studies (Al-Jifri \& Citron, 2009; Dahmash, Durand, \& Watson, 2009), in order to test the effect of intangible measures, the book value of equity is divided into different components:

$$
\text { Model 2: } \text { MVPS }_{\mathrm{it}}=\beta_{0}+\beta_{1}(\text { BVPS-INT })_{\mathrm{it}}+\beta_{2} \mathrm{EPS}_{\mathrm{it}}+\beta_{3} \mathrm{INT}_{\mathrm{it}}+\varepsilon
$$

where BVPS-INT: book value of equity (per share) minus intangible assets (per share) representing the equity value if a specific intangible item has not been recorded in financial statements (all intangibles are considered as distinct components of equity book value and this is why we should subtract from the book value); earnings per share (EPS): Net income after taxes and before extraordinary items, discontinued operations, special and non-operating items; INT: intangible assets per share of company $i$ of year $t$;

Then, in order to assess a potential association between each single class of intangible assets provided by 
Orbis Database, we elaborate a third regression model following reported:

$$
\text { Model 3: } \text { MVPS }_{\text {it }}=\beta_{0}+\beta_{1}(\text { BVPS-INT) })_{\text {it }}+\beta_{2} \text { EPS }_{\text {it }}+\beta_{3} G_{i t}+\beta_{4} R \& D_{i t}+\beta_{5} \text { OTHER }_{i t}+\varepsilon
$$

where $\mathrm{G}$ (goodwill): the goodwill per share recorded in the statement of financial position of company $i$ at the end of year $t$; research and development (R \& D) expenditures; other intangible assets (OTHER) that contained start-up costs, trademarks and licenses or other capitalized costs, such as marketing and advertising expenses).

In the analysis, we assume that number of shares is a deflator by using per share values of prices and accounting variables, consistent with Davis-Friday, Eng, and Liu (2006). The above analysis is built on balanced panel data.

\section{Descriptive Statistics and Correlation}

Table 1 reports descriptive statistics indicating that:

- the variability of the equity's book value measures on Italian companies is greater than the variability of the earnings measures (40.64 vs. 26.10);

- the mean of the equity's variables on Italian companies is positive (8.26) while the mean of earnings is negative and equal to -1.83 ; the mean of total intangible asset is 2.07 per share;

- the mean of market value per share (MVPS) accounts for 9.59.

Moreover, Table 2 presents the Pearson correlation coefficients of Italian companies for all level and changes of book values, earnings and intangible assets variable and each single item of intangibles.

Table 1

Descriptive Statistics

\begin{tabular}{llllll}
\hline Variables & Obs. & Mean & Std. dev. & Min. & Max. \\
\hline MVPS & 2,016 & 9.5930 & 38.1700 & 0 & $1,092.01$ \\
BVPS & 2,016 & 8.2595 & 40.6369 & -89.411 & 623.821 \\
(BVPS-INT) & 2,016 & 5.7734 & 39.6841 & -93.293 & 613.813 \\
EPS & 2,016 & -1.8345 & 26.1017 & -484.069 & 71.37 \\
INT & 2,016 & 2.0785 & 4.0151 & 0 & 32.69 \\
G & 2,016 & 1.1669 & 3.6473 & -2.52 & 66.274 \\
R \& D & 2,016 & 0.0809 & 0.7272 & -0.071 & 18.229 \\
OTHER & 2,016 & 1.0062 & 2.4682 & 0 & 27.702 \\
\hline
\end{tabular}

Table 2

Correlation Matrix

\begin{tabular}{|c|c|c|c|c|c|c|c|c|}
\hline & MVPS & BVPS & BVPS-INT & EPS & INT & $\mathrm{G}$ & OTHER & R \& D \\
\hline MVPS & 1 & & & & & & & \\
\hline BVPS & 0.627 & 1 & & & & & & \\
\hline BVPS-INT & 0.605 & 0.991 & 1 & & & & & \\
\hline EPS & 0.069 & -0.487 & -0.502 & 1 & & & & \\
\hline INT & 0.222 & 0.116 & 0.023 & 0.037 & 1 & & & \\
\hline G & 0.174 & 0.120 & 0.044 & 0.024 & 0.449 & 1 & & \\
\hline OTHER & 0.217 & 0.113 & 0.045 & 0.039 & 0.623 & 0.220 & 1 & \\
\hline$R \& D$ & 0.785 & 0.635 & 0.615 & 0.077 & 0.222 & 0.150 & 0.206 & 1 \\
\hline
\end{tabular}

\section{Regression Results}

We use the panel data analysis with fixed effect to estimate the parameters of the model setting all the data on Stata software; this approach does not provide an analysis of variance table and does not correct the $R^{2}$ and $\mathrm{F}$ 
statistics. To check for potential multicollinearity issues, variance inflation factor (VIF) was computed for the three models.

Tables 3, 4, and 5 report the estimation results of the three models, using the fixed effects approach.

The $F$ statistics for each of the three models are presented in the last line of each table: The $F$-test shows the values of 557.52, 392.52, and 432.33, respectively, and in each of the three cases, the null hypothesis is rejected in favour of the fixed group effect model $(p<0.0000)$.

We also set the Hausman specification test to test whether the individual effects are uncorrelated with the other regressors in the model. Although the output is not reported, in the three models, we record a significant $p$-value (Prob. $>c 2$ smaller than 0.01). So, the fixed effect model is preferred. All models are statistically significant at the $0.1 \%$ level.

In the Model 1, BVPS and EPS are statistically significant at the $0.1 \%$ level; both variables were found to be positively related to stock price, in particular, the book value of equity is found to be more associated with a coefficient of 0.63 while the coefficient for earnings is 0.58 . The reliability of the model demonstrated by the $\mathrm{R}$-squared within is $38.38 \%$.

Table 3

Output of Model 1

Fixed-effects (within) regression
R-sq:
Within $=0.3838$
Between $=0.7919$
Overall = 0.5758

Notes. Sig.: ${ }^{*} 0.10,{ }^{* *} 0.05 .{ }^{* * *} 0.01,{ }^{* * * *} 0.001 ; \mathrm{F}(2,1790)=557.52 ;$ Prob. $>\mathrm{F}=0.0000$

Shifting to the Model 2, BV-INT, EPS, and INT are statistically significant at the $0.1 \%$ level and the positive coefficients are respectively $0.63,0.58$, and 1.14 ; the variable INT measured by the value of intangible assets as a whole is the more positive variable associated to stock price: on average for each $1 €$ allocated to Intangible Asset investments the stock price will enhance on $€ 1.13$. The reliability of the Model 2 is shown by an R-Squared within of $39.69 \%$ that has slightly increased compared to Model 1 .

Finally, the Model 3 with the assessment of the impact of each single variable of intangible assets (goodwill, R \& D expense and other intangibles) on stock price.

With regard to the single item of intangible assets, all variables are significant at $0.1 \%$, expect for the goodwill that is significant at $1 \%$. Furthermore, all variables are positive related to market values, in particular the value of R \& D expenditures that shows a coefficient of 24.61, followed by OTHER with 0.91 value of coefficient. The interesting result to be provided relied to the improvement of the model reliability: The R-squared goes to $54.74 \%$ with an increase of $+15.05 \%$ compared to the Model 2 .

Table 4 
Output of Model 2

\begin{tabular}{|c|c|c|c|c|}
\hline \multicolumn{5}{|c|}{ Fixed-effects panel regression } \\
\hline \multicolumn{5}{|l|}{ R-sq: } \\
\hline \multicolumn{5}{|c|}{ within $=0.3969$} \\
\hline \multicolumn{5}{|c|}{ between $=0.8071$} \\
\hline \multicolumn{5}{|c|}{ overall $=0.5850$} \\
\hline \multicolumn{5}{|c|}{ Corr $\left(\mathrm{u} \_\mathrm{i}, \mathrm{Xb}\right)=0.4278$} \\
\hline MVPS & Coef. & Std. err. & $t$ & [95\% Conf. Interval] \\
\hline (BVPS-INT) & $0.6292^{* * * *}$ & 0.0245 & 25.62 & 0.58110 .6774 \\
\hline EPS & $0.5828^{* * * *}$ & 0.0503 & 11.58 & 0.48410 .6816 \\
\hline INT & $1.1366^{* * * *}$ & 0.1883 & 6.03 & 0.76721 .5061 \\
\hline cons & 4.666513 & 0.6396 & 7.3 & 3.41195 .9211 \\
\hline
\end{tabular}

Notes. Sig.: ${ }^{*} 0.10,{ }^{* *} 0.05,{ }^{* * *} 0.01,{ }^{* * * *} 0.001 ; \mathrm{F}(3,1789)=392.52 ;$ Prob. $>\mathrm{F}=0.0000$.

This indicates that the separate intangible assets information (recognized goodwill, R \& D costs and other intangibles) consistently improves the model reliability. In respect of our hypothesis addressed, these models show that earnings and intangibles are highly significantly related to market values. This suggests that investors considered intangible assets figures as relevant components for their decision-making.

Table 5

Output of Model 3

\begin{tabular}{|c|c|c|c|c|}
\hline $\begin{array}{l}\text { Fixed-effects } \\
\text { R-sq: } \\
\text { within }=0.547 \\
\text { between }=0.7 \\
\text { overall }=0.66\end{array}$ & egression & & & \\
\hline MVPS & Coef. & Std. err. & $t$ & [95\% Conf. Interval] \\
\hline (BVPS-INT) & $0.2321^{* * * *}$ & 0.0271 & 8.55 & 0.17880 .2854 \\
\hline EPS & $0.2767^{* * * *}$ & 0.0454 & 6.09 & 0.18750 .3658 \\
\hline G & $0.4655^{* * *}$ & 0.1869 & 2.49 & 0.09890 .8321 \\
\hline$R \& D$ & $27.6140^{* * * *}$ & 1.1759 & 23.48 & 25.307629 .9204 \\
\hline OTHER & $0.9087^{* * * *}$ & 0.2787 & 3.26 & 0.36211 .4554 \\
\hline cons & 5.0680 & 0.5545 & 9.14 & 3.98046 .1556 \\
\hline
\end{tabular}

Notes. Sig.: ${ }^{*} 0.10,{ }^{* *} 0.05,{ }^{* * *} 0.01,{ }^{* * * *} 0.001 ; \mathrm{F}(5,1787)=432.33 ;$ Prob. $>\mathrm{F}=0.0000$.

\section{Conclusion and Discussion}

This study tests whether recognized intangible assets recognized value relevant for investors in the Italian context. At first, we measure the impact of the intangible assets as a whole category of the balance sheet; then, we test the impact of each single item (goodwill, R \& D expenses and other intangibles). When testing the value relevance of each intangible assets (Model 3), we include three sub-categories (goodwill, R \& D and other intangibles) that have found to be positively and significantly associated with dependent variable.

Our evidence suggests that intangibles can explain the securities price of Italian stock market over the past ten years providing empirical support to the increasing role of intangibles.

Regarding the implications, it is useful to mention the relevance of our paper for scholars, accountants and financial analysts. First, there were no previous studies that disaggregated investments in intangible assets into sub-components and valued the effect of each component to market value in Italy; secondly, we have discussed 
the relationships for the most recent period 2010-2018. We could therefore check the impact of previous investments in intangibles on market value at a time of maturity of crisis in Italy starting from 2010; and, on the other hand, the effect of these investments on market value during the crisis period. From a managerial perspective, the results of this paper show that the investments in competencies linked to intangible resources, especially those related to research and development, can have positive impact on a company's competitiveness, and consequently, on value creation.

This work presents also several limitations that can be considered for future research opportunities: The first refers to the small sample we worked with. Furthermore, the study is limited only to Italian companies. Possible lines of future research are to enlarge the selected sample and include other European companies listed in other stock exchanges; furthermore, it would be useful to test the effect of structural capital variables on the securities prices of the company's intangibles.

Our study provides further explanations and evidence into how intangibles can be value relevant among the largest Italian companies and highlights the implications of IFRS adoption on securities price of Italian publicly traded companies. Future research avenues will aim to test the possible impact of different cultural characteristics and various institutional settings on the relevance of intangibles.

\section{References}

Aboody, D., \& Lev, B. (1998). The value-relevance of intangibles: The case of software capitalization. Journal of Accounting Research, 36, 161-191.

Abrahams, T., \& Sidhu, B. K. (1998). The role of R \& D capitalisations in firm valuation and performance measurement. Australian Journal of Management, 23(2), 169-183.

Al-Jifri, K., \& Citron, D. (2009). The value relevance of financial statement recognition versus note disclosure: Evidence from goodwill accounting. European Accounting Review, 18(1), 123-140.

Ball, R. (2006). International Financial Reporting Standards (IFRS): Pros and cons for investors. Accounting and Business Research, 36(Suppl.), 5-27.

Barth, M. E., \& Clinch, G. (1998). Revalued financial, tangible, and intangible assets: Associations with share prices and non-market-based value estimates. Journal of Accounting Research, 36, 199-233.

Barth, M. E., Beaver, W. H., Hand, J. R. M., \& Landsman, W. R. (2005). Accruals accounting based valuation models and the predictions of equity values. Journal of Accounting, Auditing \& Finance, 20, 311-345.

Barth, M. E., Hodder, L. D., \& Stubben, S. R. (2008). Fair value accounting for liabilities and own credit risk. The Accounting Review, 83(3), 629-664.

Beisland, L. A. (2009). A review of the value relevance literature. The Open Business Journal, 2, 7-27.

Brown, S., Lo, K., \& Lys, T. (1999). Use of $\mathrm{R}^{2}$ in accounting research: measuring changes in value relevance over the last four decades. Journal of Accounting and Economics, 28(2), 83-115.

Cazavan-Jeny, A., \& Jeanjean, T. (2003). Value relevance of R \& D reporting: A signalling interpretation. Working Paper 2003-12, CEREG, University Paris IX Dauphine, France.

Chalmers, K., Clinch, G., Godfrey, J. M., \& Wei, Z. (2012). Intangible assets, IFRS and analysts' earnings forecasts. Accounting \& Finance, 52(3), 691-721.

Collins, D. W., Maydew, E. L., \& Weiss, I. S. (1997). Changes in the value-relevance of earnings and book values over the past forty years. Journal of Accounting \& Economics, 24(1), 39-67.

Dahmash, F., Durand, R., \& Watson, J. (2009). The value relevance and reliability of reported goodwill and identifiable intangible assets. British Accounting Review, 41(2), 120-137.

Daum, J. H. (2003). Intangible assets and value creation. Chichester, West Sussex, England: John Wiley \& Sons.

Davis-Friday, P., Eng, L., \& Liu, C. (2006). The effects of the Asian crisis, corporate governance and accounting system on the valuation of book value and earnings. International Journal of Accounting, 41, 22-40.

Dontoh, A., Radhakrishnan, S., \& Ronen, J. (2007). Is stock price a good measure for assessing value-relevance of earnings? An empirical test. Review of Managerial Science, 1(1), 3-45. 
Dumontier, P., \& Labelle, R. (1998). Accounting earnings and firm valuation: The French case. European Accounting Review, $7(2), 163-183$.

Dumontier, P., \& Raffournier, B. (2002). Accounting and capital markets: a survey of the European evidence. European Accounting Review, 11(1), 119-151.

Ely, K., \& Waymire, G. (1999). Accounting standard-setting organizations and earnings relevance: Longitudinal evidence from NYSE common stocks, 1927-93. Journal of Accounting Research, 37(2), 293-317.

EU Regulation No 1606/2002. (2002). European Parliament and of the Council of 19 July 2002 on the application of the international accounting standards.

Francis, J., \& Schipper, K. (1999). Have financial statements lost their relevance? Journal of Accounting Research, 37(2), 319-352.

Godfrey, J., \& Koh, P. S. (2001). The relevance to firm valuation of capitalising intangible assets in total and by category. Australian Accounting Review, 11(24), 39-48.

Goodwin, J., \& Ahmed, K. (2006). Longitudinal value relevance of earnings and intangible assets: Evidence from Australian firms. Journal of International Accounting, Auditing and Taxation, 15(1), 72-91.

Goodwin, J., Ahmed, K., \& Heaney, R. (2008). The effects of International Financial Reporting Standards on the accounts and accounting quality of Australian firms: A retrospective study. Journal of Contemporary Accounting \& Economics, 4(2), 89-119.

Graham, R., King, R., \& Bailes, J. (2000). The value relevance of accounting information during a financial crisis: Thailand and the 1997 decline in the value of the baht. Journal of International Financial Management \& Accounting, 11(2), 84-107.

Hail, L. (2013). Financial reporting and firm valuation: relevance lost or relevance regained? Accounting and Business Research, 43(4), 329-358.

Harris, T. S., Lang, M., \& Möller, H. P. (1994). The value relevance of German accounting measures: An empirical analysis. Journal of Accounting Research, 32(2), 187-209.

Harto, P., \& Paranti, R. (2017). Value relevance and reliability of intangible assets around the IFRS adoption: Case of Indonesia. Advanced Science Letters, 23(8), 7079-7082.

IASB (2004c). IAS 38 - Intangible Assets (Revised). London: International Accounting Standards Committee Foundation.

IASB (2008a). IFRS 3 - Business Combinations. London: International Accounting Standards Committee Foundation.

Joos, P., \& Lang, M. (1994). The effects of accounting diversity: Evidence from the European Union. Journal of Accounting Research, 32, 141-168.

Kimouche, B., \& Rouabhi, A. (2016). The impact of intangibles on the value relevance of accounting information: Evidence from French companies. Intangible Capital, 12(2), 506-529.

Lam, K. C., Sami, H., \& Zhou, H. (2013). Changes in the value relevance of accounting information over time: Evidence from the emerging market of China. Journal of Contemporary Accounting \& Economics, 9(2), 123-135.

Landsman, W. R., \& Maydew, E. L. (2002). Has the information content of quarterly earnings announcements declined in the past three decades? Journal of Accounting Research, 40(3), 797-808.

Lev, B. (2001). Intangibles: Management, measurement, and reporting. Washington, DC: Brookings Institution Press.

Lev, B., \& Zarowin, P. (1999). The boundaries of financial reporting and how to extend them. Journal of Accounting Research, 37(2), 353-385.

Marquardt, C. A., \& Wiederman, C. I. (2004). The effect of earnings management on the value relevance of accounting information. J Bus Finance Account, 31(3-4), 297-332.

Ohlson, J. A. (1995). Earnings, book values and dividends in security valuation. Contemporary Accounting Research, 11, 661-687.

Oliveira, L., Rodrigues, L. L., \& Craig, R. (2010). Intangible assets and value relevance: Evidence from the Portuguese stock exchange. The British Accounting Review, 42(4), 241-252.

Reilly, R. F., \& Schweihs, R. P. (1999). Valuing intangible assets. New York: McGraw-Hill.

Sahut, J. M., Boulerne, S., \& Teulon, F. (2011). Do IFRS provide better information about intangibles in Europe? Review of Accounting and Finance, 10(3), 267-290.

Schipper, K. (2005). The introduction of international accounting standards in Europe: Implications for international convergence. European Accounting Review, 14(1), 101-126.

Shahwan, Y. (2008). Qualitative characteristics of financial reporting: A historical perspective. Journal of Applied Accounting Research, 9(3), 192-202 
Smith, G.V. (2000). Valuation of intellectual property and intangible assets. New York: Wiley.

Sougiannis, T. (1994). The accounting based valuation of corporate R \& D. The Accounting Review, 69(1), 44-68.

Wang, G. (2018). The differential impact of investor sentiment on the value relevance of book value versus earnings. International Journal of Critical Accounting, 10(6), 462-490.

Zhao, R. (2002). Relative value relevance of R \& D reporting: An international comparison. Journal of International Financial Management \& Accounting, 13(2), 153-174. 